\title{
Minister of Safety and Security v Sekhoto 20111 SACR 315 (SCA)
}

\author{
A critique of reasonableness as the fifth jurisdictional fact for a lawful arrest
}

\section{Introduction}

The right to liberty of the person has always been accorded protection by our courts even before the advent of the Constitution. This right has been constitutionalised in the post-apartheid Constitutions. Section 12 of the Constitution of 1996 guarantees everyone's right to freedom and security of the person, which includes the right "not to be deprived of freedom arbitrarily or without just cause". Like all rights in the Bill of Rights, the right to freedom is not absolute and can, where it is reasonable and justifiable, be limited. Section 36 of the Constitution provides for the general limitation of the rights in the Bill of Rights. Arrest by police officials is one of the most common means of limiting an individual's right to freedom. Arrest may take one of two forms: arrest without a warrant and arrest with a warrant (in terms of ss $40 \& 43$ of the Criminal Procedure Act 51 of 1977 (CPA) respectively). This article will not concern itself with the latter form, ie arrest with a warrant. Suffice it to say unlike a warrantless arrest, arrest on a warrant is subject to judicial oversight. For an arrest without a warrant to be lawful, it has to satisfy the four jurisdictional facts set out in Duncan $v$ Minister of Law and Order (19862 SA 805 (A) $818 \mathrm{G}-\mathrm{H}$ ). Where these factors are complied with, the arrest is deemed lawful regardless of its reasonableness. These factors are:

(a) the arrestor must be a peace officer;

(b) she must entertain a suspicion;

(c) the suspicion must be that the suspect has committed an offence listed in schedule 1 of the CPA;

How to cite: Msaule 'Minister of Safety and Security v Sekhoto 20111 SACR 315 (SCA): A critique of reasonableness

http:/dx doi.org/10.17159/2225-7160/2015/v48n1a16 
(d) such suspicion must be based on reasonable grounds.

The position postulated above accurately reflects the preconstitutional era. Since the advent of the Constitution, several High Courts have held that this position falls short of affording the right to freedom the pride of place it deserves in our constitutional state. For instance, in Louw v Minister of Safety and Security (2006 2 SACR 178 (T) 185a-187g), Bertelsman J purported to widen the set of jurisdictional facts which a lawful arrest has to satisfy. According to the court, in addition to satisfying the traditional jurisdictional facts for a lawful arrest, time was ripe to evaluate the lawfulness of an arrest through the prism of the Bill of Rights. There is no need in a society founded on the values of equality, dignity and freedom to deprive individuals of their freedom where less invasive means could be used to achieve the objects of arrest - to bring a person suspected of having committed a crime to court. In essence, Bertelsman J demanded that the police action of arrest, in addition to satisfying the traditional jurisdictional facts, has to be objectively reasonable, taking into account whether milder methods of bringing a suspect before court could not be as effective as an arrest. This means that where methods short of arrest could ensure that the suspect appears in court to answer the charges against her, such milder methods should be preferred over arrest (see amongst others Minister of Safety and Security v Sekhoto 20101 SACR 388 (FB) par 24 (Sekhoto a quo case); Mvu $v$ Minister of Safety and Security 20092 SACR 291 (GSJ); Gellman v Minister of Safety and Security 20081 SACR 446 (W)). However, this view has not been unanimously shared by the High Courts (see Charles $v$ Minister of Safety and Security 20073 SACR 137 (W)). The Supreme Court of Appeal (SCA) had an opportunity to reconcile these contradictory views. In Minister of Safety and Security $v$ Sekhoto (2011 1 SACR 315 (SCA) (Sekhoto case)) the SCA favoured the conservative view espoused in the Charles case in this regard.

\section{Facts of the Case}

The brief facts in this case were as follows: The first and second plaintiffs were arrested on allegations of being in possession of suspected stolen stock and stock theft respectively. After receiving a report of stolen stock from an informer, police paid a visit to the first plaintiff's home where they found bags containing seven sheepskins in an outbuilding. The first plaintiff's father informed the police that those skins belonged to the first plaintiff who was not around at the time. The first plaintiff arrived whilst the police were still there. The police asked him for an explanation about the sheep skins. The first plaintiff's explanation was to the effect that he had bought them but could not remember where. Mention should be made that those skins carried the same mark. The police found the first plaintiff's explanation implausible. The first plaintiff was arrested. The second plaintiff was arrested on the basis that the first plaintiff had later told the police that he had received the sheepskins from the second plaintiff. They were then prosecuted and discharged at the end of the state's case (Sekhoto a quo case par 29). 


\section{Judgment and Analysis}

The court a quo found that the traditional jurisdictional facts for a lawful arrest were satisfied. However, the court found for the plaintiffs' on the basis that the respondent had failed to satisfy the fifth jurisdictional fact. (Sekhoto a quo par 28; see Sekhoto case par 10). The respondent appealed to the SCA. The SCA found the judgments of the High Courts' in this regard troubling. The SCA held that the present and other High Courts' formulation of the fifth jurisdictional fact is not borne out by the principles of interpretation. As the starting point, the SCA pointed out that it was not clear that when formulating the fifth jurisdictional fact the High Courts did so by directly applying the Bill of Rights, by developing the common law, in line with section 39 of the Constitution, or by way of interpreting section 40(1) of the CPA (Sekhoto case par 14).

The SCA found the High Courts' interpretation of section 40(1)(b) of the CPA problematic in that these courts had failed to deal with the constitutionality or otherwise of this provision. Secondly, relying on Investigating Directorate: Serious Economic Offences $v$ Hyundai Motor Distributors (Pty) Ltd (2001 1 SA 545 (CC) (Hyundai case)), the SCA held that with the interpretational aids at its disposal, it was unable to conclude that the fifth jurisdictional fact could be inferred from the proper reading of section 40(1) of the CPA without straining the language of the provision. Lastly, the SCA found that it was not clear whether the development of the fifth jurisdictional fact was through the development of common law (see parr $24 \& 14$ ).

The first and third concerns were disposed of easily. With regard the first ground, the SCA found that absent the finding of unconstitutionality of this provision, these courts were not entitled to read anything into a clear text. As to the third ground, the SCA held that the fifth jurisdictional fact could not be developed through the common law as the common law regarding this aspect has been superseded by legislation (parr 22-24). In relation to the second ground, the SCA held that although courts are under an obligation to read legislation through the prism of the values of the Bill of Rights in terms of section 39(2) of the Constitution, this was not possible in each and every case. This was one of those cases. According to the SCA, the text of section 40(1)(b) was not amenable to the interpretation ascribed to it by the High Courts. In this regard, the SCA drew a distinction between interpreting legislation in terms of section 39(2) of the Constitution (reading down) and the process of reading words into or severing them from a statutory provision that has been declared unconstitutional (par 15). With regard to the former, the court need not declare an otherwise unconstitutional provision invalid but read it in conformity with the values of the Bill of Rights to save it from invalidity. With regard to the latter, the court must declare a provision unconstitutional before saving it from invalidity by either reading-in or severing words from the provision (Currie \& De Waal The Bill of Rights Handbook (2013) 67). When a court reads a provision in line with the values of the Bill of Rights that is usually the end of the matter. 
For instance, if such a finding is made by a high court the matter would not be referred to the Constitutional Court for confirmation. In other words such a provision is not declared invalid. However, where a reading-in or severance is used the matter must be referred to the Constitutional Court to confirm the unconstitutionality of the provision (see s 172 of the Constitution).

In the current case, the High Courts purported to rely on the interpretational clause to reach their conclusions. The SCA held that the reliance on section 39(2) was flawed. In this regard the SCA held that the reason the High Courts' found a fifth jurisdictional requirement hidden somewhere in section 40(1)(b) was that the High Courts failed to draw a distinction between the objects of arrest and the motive for the arrest. It is the object, and not the motive, that is relevant in the determination of whether an arrest is lawful or not (par 31). According to the SCA, once the jurisdictional facts are satisfied and the object of the arrest is to bring the accused to justice, then the discretion whether to arrest or not arises. The arrestor is not obliged to affect an arrest (par 28). If the arrestor exercises her discretion within the bounds of rationality, such an arrest cannot be said to be unlawful. This is more so because section 40(1)(b) is silent on how the discretion must be exercised. In this regard, the SCA found that the manner in which the discretion to arrest is to be exercised must be discovered by inference in accordance with the ordinary rules of construction. In the present case, once the object of arrest (ie to bring the arrestee to justice) is the underlying reason for an arrest and the arrestor has rationally exercised her discretion, such an arrest could not be said to be unlawful. It is common cause that there are a number of avenues available to the arrestor to bring the arrestee to justice, however, that does not mean that the arrestor must be faulted for having chosen arrest over other methods. In other words, the question to be asked should not be whether the arrestee was brought to justice in the best possible manner, but whether the arrestor had the intention to bring the arrestee to justice and that she exercised her discretion properly. The arrestor exercises her discretion unlawfully when she invokes the power to arrest for a purpose not contemplated by the legislator (parr 30-31). It is common cause that the release of the arrestee after she has been arrested requires a judicial evaluation to determine whether it is in the interests of justice to do so. In other words, the arrestor's role in this regard is circumscribed by law. If a peace officer were to be required to arrest only in circumstances were she is satisfied that the suspect would not attend trial, the statutory structure relating to bail will be undermined (parr 30-44). The SCA has summarised this position (par 44):

[I]t seems to me to follow that the enquiry to be made by the peace officer is not how best to bring the suspect to trial: the enquiry is only whether the case is one in which that decision ought properly to be made by a court (or a senior officer). Whether his decision on that question is rational naturally depends upon the particular facts but it is clear that in cases of serious crime - and those listed in Schedule 1 are serious, not only because the legislature thought so - a peace officer could seldom be criticised for arresting a suspect 
for that purpose. On the other hand there will be cases, particularly where the suspected offence is relatively trivial, where the circumstances are such that it would clearly be irrational to arrest.

It is worth mentioning that the arrestor is not required to conduct a hearing before affecting an arrest. That question arises later, when the arrestee is at the police station (depending on what offence the arrestee had committed) or when he appears in court. Once the jurisdictional facts are satisfied then a discretion, which must be exercised rationally, arises (National Commissioner of Police v Coetzee 20131 SACR 358 (SCA) par 14). It is for this reason that the SCA found that if the fifth jurisdictional fact can indeed be read into section 40(1)(b) of the CPA, by parity of reasoning, it must also be read into section 43 of the CPA. Section 43 of the CPA provides for the arrest of a suspect on the strength of a warrant of arrest. The text of section 43 of the CPA is not susceptible to such a reading (par 23). However, it is noteworthy that even when a suspect is arrested on the strength of a warrant, the arrestor must still exercise the discretion whether to arrest or not (par 28).

\section{Is the Formulation of The Fifth Jurisdictional Fact Justifiable?}

It is difficult to comprehend why the SCA had difficulty establishing the route used by the High Courts to formulate the fifth jurisdictional fact. Firstly, the constitutionality or otherwise of section 40(1) of the CPA was not at issue in the High Courts that developed the fifth jurisdictional fact. With regard to the second concern that the High Courts failed to explain the basis for widening the traditional jurisdictional facts, the High Courts relied on section 39(2) of the Constitution. Despite the SCA claims that the interpretational aids at its disposal do not justify the development of the fifth jurisdictional fact (the second SCA concern), the High Courts' read section 40(1)(b) in a manner that embraced the values underlying our constitutional project as per section 39(2) of the Constitution injunction. It is not clear where the confusion of the SCA in this regard stems from. In the Sekhoto a quo case, the court specifically refers to the Constitution's dictate to interpret legislation in the manner that must promote "the spirit, purport and objects of the Bill of Rights" (Sekhoto a quo par 27). In this context, this principle means that legislation is to be presumed constitutional. In other words, wherever possible legislation must be read consistently with the Constitution. Devenish eloquently sums up this approach as follows (Devenish A Commentary on the South African Bill of Rights (1999) 600):

[S]hould a statute be capable of being interpreted in more than one way, one resulting in validity and the other in invalidity, the court should presume that the legislature intended to act in a way that is compatible with the constitution.

Section 39(2) of the Constitution gives effect to this principle (Devenish supra 601). This provision provides that "when interpreting any legislation, and when developing the common law or customary law, 
every court, tribunal or forum must promote the spirit, purport and objects of the Bill of Rights". It provides a leeway to courts to interpret a provision of a statute that otherwise would be unconstitutional liberally to save it from invalidity. The caveat is that the values and principles underlying the Constitution be upheld without straining the language of the provision. In the words of Devenish (supra 600-601):

This [the interpretation of legislation in light of section 39(2)] does not necessitate that the constitution be interpreted restrictively in order to accommodate the impugned statute. The constitution should, as indicated above, be interpreted liberally, after which the statute should be analysed to determine whether it can be construed in a manner that is in accordance with the provisions, values and principles of the constitution.

De Ville takes this point further by stating that (De Ville Constitutional and Statutory Interpretation (2000) 266):

A new consideration the courts would have to take account of in this regard is the principle that where two interpretations of a statutory provision are possible - the one leading to the validity thereof and the other to its invalidity (due to its conflict with the provisions of the Constitution) - the firstmentioned interpretation is to be followed. It may namely in certain instances occur that construing a provision as directory instead of peremptory leads to the invalidity of that provision or vice versa. One must follow the construction which leads to the validity of the provision.

Are the SCA's concerns regarding the formulation of the fifth jurisdictional fact justified? As already stated, the High Courts relied on section 39(2) of the Constitution to formulate the fifth jurisdictional fact. This method of interpretation (s 39(2)) was applied in Govender v Minister of Safety and Security (2001 4 SA 273 (SCA)) in relation to section 49(1) of the CPA. In that case, the SCA found that the threshold requirement for the exercise of power conferred by that provision was very low, as the arresting officer had only to be satisfied that the legislative requirements for the use of force (even fatal force) are present without having to adhere to the standard of reasonableness (par 21 et seq). The formulation of the fifth jurisdictional fact in the manner the High Courts did is therefore, nothing alien to our constitutional jurisprudence. The Constitutional Court has since confirmed the soundness of the interpretation adopted in the Govender case (see Ex parte Minister of Safety and Security: In re $S$ $v$ Walters 20024 SA 613 (CC) par 39 (Walters case)).

In the context of this discussion, given a number of choices open to the arrestor with regard to methods of bringing the suspect before court, it is therefore, implicit that the arrestor will have to apply her mind as to the appropriate method to use (see Hyundai supra par 37). Section 38 of the CPA specifically lists four "methods of securing the attendance of an accused in court for her trial", ie arrest; summons; written notice and indictment. Surely the CPA does not prescribe that a person, who is reasonably suspected of committing a schedule 1 offence, must be arrested. This is made clear by the usage of the modal verb "may" in section 40 of the CPA which denotes that the arrestor has a discretion. 
Joubert intimates that wherever a police official exercises a discretion in terms of the law, she has to be familiar with the possible alternatives open to her and must endeavour to avoid choosing the one infringing the rights of the individual (Joubert Applied Law for Police Officials (2001) 17). This, of necessity, requires that an arrestor weigh the appropriate method from the ones available to him, given the circumstances of each case. To argue otherwise would be to undermine the structure and objectives of the CPA pertaining to bringing suspects before court. That the arrestor has to choose an appropriate method of bringing the accused before court is obvious from the CPA and in particular section 38.

In addition to failing to apply the interpretational principles, the SCA found that the reasons offered by the High Courts for the formulation of the fifth jurisdictional fact cannot withstand scrutiny. The SCA held that if an arrest accords with the traditional jurisdictional facts, it could not be unlawful. Once the jurisdictional facts are present, the arresting officer is entitled to exercise her discretion as she sees fit (Sekhoto case parr 2829). The SCA seems to have narrowed down the grounds for unlawful arrest to situations where the arresting officer "knowingly invokes the power to arrest for a purpose not contemplated by the legislator" (par 30). The SCA asserts that where the intention of the arrestor is to bring the arrestee to justice, no claim for unlawful arrest could lie despite the circumstances at the time of the arrest (par 30). Where an arrest is perpetrated for reasons other than bringing the arrestee to justice, such an arrest is in fraudem legis and amounts to the misuse of the power granted by the legislation and is therefore, unlawful. According to the SCA, the High Courts failed to draw a distinction between situations where the exercise of arrest power amounted to abuse and where the intention has always been to bring the arrestee before court; the High Courts conflated the motive and objects of arrest. In short, where the arrest was motivated by malice, a claim lies not because the arrestor failed to exercise her discretion reasonably, but in the fact that the arrest was not for the purpose for which it was meant (par 31).

The standard of rationality is not breached because the arrestor has opted for the less perfect (or even imperfect) method at the time: "The standard is not perfection, or even optimum, judged from the vantage of hindsight so long as the discretion is exercised in accordance with the jurisdictional facts the standard is not breached" (par 39). The standard is not breached for as long as it remains "within the bounds of rationality" (par 39). Once the legislative requirements for the exercise of discretion to arrest are satisfied, such an arrest cannot be said to be unlawful. In the context of section 40(1)(b) of the CPA, the legislature has failed to provide a matrix within which the arrestor has to exercise her discretion and therefore, such limits are to be discovered by inference (parr 40-41). The SCA intimates that if the arrestor has exercised her discretion rationally, that should be the end of the matter. The rationality to which the SCA seems to refer to is choosing one of the available options of bringing the suspect to justice without really applying one's mind to the effects that the chosen method would have on the subject. 
Failure to use milder methods, without any justifiable reason, where the CPA grants the arrestor that discretion, should surely amount to a failure to exercise one's discretion reasonably, if not failure to act in accordance with the objects of the empowering legislation. This position is confirmed in the Govender case (see par 21). In that case, the plaintiff's seventeen year old son was involved in a motor car theft. After being cornered by the police, the plaintiff's son attempted to run away despite verbal warnings and a warning shot being fired. The police officer then shot the plaintiff's son in the back, fracturing his spine. The police official purportedly acted in terms of section 49(1) of the CPA (before its amendment) (Govender supra par 5). This provision authorised police officers to use force (even deadly force) when attempting to effect an arrest and the arrestee flees or attempts to flee and the use of force is reasonably necessary to overcome the arrestee from fleeing. The High Court found the shooting lawful in the following terms (Govender supra par 7):

[I]n my view the force used was reasonable and necessary and proportionate to the offence of motor vehicle theft. The public interest involved in the use of deadly force as a last resort to arrest a fleeing car thief relates primarily to the serious nature of this crime, its increasing prevalence throughout this country, and the public's interest in the apprehension, prosecution and punishment of car thieves. In the result in my view the shooting was justified by section 49(1).

Mention should be made that in the Govender case, the constitutionality of section 49(1) was not at issue (par 9). Instead, the plaintiff urged the SCA that, in addition to taking into account the "proportionality between the degree of force used and the seriousness of the crime for which the victim is suspected" (Govender supra par 16), the reasonableness and justifiability of the police conduct must be taken into consideration (par 17). The court agreed with the plaintiff. The SCA found the approach of the High Court inappropriate. The SCA reaffirmed the standard of reasonableness as a yardstick for measuring the conduct expected of an arresting officer in terms of this provision as follows (par 21):

[I]n licensing only such force, necessary to overcome resistance or prevent flight, as is 'reasonable', section 49(1) implies that in certain circumstances the use of force necessary for the objects stated will nevertheless be unreasonable. It is the requirement of reasonableness that now requires interpretation in the light of constitutional values. Conduct unreasonable in the light of the Constitution can never be 'reasonably necessary' to achieve the statutory purpose.

To underscore this sentiment, the SCA held that in relying on section 49(1) of the CPA, the arrestor must also take into consideration the rights of the fugitive (par 19). The court expanded factors that the arrestor has to take into consideration when relying on section 49(1) of the CPA to include whether, at the time and under the circumstances, the suspect posed immediate danger to the arrestor or to members of the society or that the suspect was involved in the commission of a crime involving the 
infliction of serious bodily harm or attempt thereof (par 24). The SCA concluded that section 49(1) of the CPA could be reasonably developed to encompass the extended requirements for the lawful reliance on the provision.

The development of the fifth jurisdictional fact is sound for another reason. It is a fundamental principle in our law that "the interpretation of legislation involves more than analysing the particular provision in question" but the holistic reading of the statute (Botha Statutory Interpretation: An Introduction for Students (2012) 128) and other legislation that directly impacts on the provision at hand (see DPP, Western Cape v Prins 20122 SACR 183 (SCA)). Thus, it could not be said that the SCA in Sekhoto embarked on the holistic reading of the CPA for reasons advanced above. If the holistic reading of this legislation was undertaken, then this was done in isolation of other instruments that have the direct bearing on the issue at hand. Having regard to the fact that the legislature is presumed to be aware of its creations, it could not be said that the CPA is the only relevant instrument in the interpretation of section 40(1)(b). For instance, section 13(3)(a) of the South African Police Service Act 68 of 1995, provides that whenever a police official exercises powers granted to her, she must do so in a manner that is reasonable. It is therefore, beyond doubt that police actions in general and of arrest in particular, must comply with the standard of reasonableness. Furthermore, the Standing Order (G)341 issued by the National Commissioner of Police emphasises that arrest must be effected as a matter of last resort.

The afore discussion makes it clear that the legislature must be taken to have contemplated that the discretion afforded to the arrestor would be exercised reasonably, having regard to all relevant surrounding circumstances, including the use of the least severe method of bringing the suspect to court (see Hyundai supra par 43). The SCA's restrictive reading of section 40(1)(b) cannot be accepted in light of the fact that the Constitution, and not the legislature, is supreme. Therefore, the satisfaction of the traditional jurisdictional facts as intended by the legislature for a lawful arrest is not determinative of the matter. These factors have to be measured against the constitutional imperative of the protection of the right to freedom of the person. The legislature's intention cannot be the yardstick with which to measure whether a constitutional right has been breached or not. Botha (supra 145) counsels that:

[I]f these values are not taken seriously and borne in mind constantly during (amongst others things) interpretation of legislation; and if we are not prepared to succumb to constitutionalism, we might as well get rid of the supreme Constitution, the justiciable Bill of Rights and rights rhetoric, and return to the former old bad days of sovereignty of Parliament and executiveminded interpretation of legislation. Otherwise we need to become serious about the rights and values in the Constitution - including a new 'constitutional' approach to statutory interpretation ... 
The SCA misdirected itself by relying on the rationality test in that it failed to recognise that rationality is a lower standard than reasonableness. In Ronald Bobroff \& Partners Inc $v$ La Guerre (2014 3 SA 134 (CC)), the Constitutional Court held that rationality is not an appropriate test to use in cases in which the infringement of fundamental rights is at stake: "It is a less stringent test than reasonableness, a standard that comes into play when the fundamental rights under the Bill of Rights are limited by legislation" (par 7). The same holds true even where the fundamental rights are limited by the exercise of discretion by a functionary. This goes against what the SCA held in the Sekhoto case.

Interestingly, the Govender case is not referred to in the Sekhoto case. Despite this, striking features between the two cases can be observed: Both cases relied on the Hyundai case and are agreed on the interpretational principles laid down in that case. However, these cases part ways as to how these principles have to be applied in difficult cases. The provisions that the two courts grappled with, in Sekhoto and Govender, differed in some regards. For instance, section 49(1) of the CPA specifically provided for the use of "reasonable force" where the suspect flees or attempts to flee. The provision, however, did not specifically enlist the offences for which deadly force could be used. The court had to chart and define circumstances under which deadly force could be used. With regard to section 40(1)(b) of the CPA, the arrestor is granted the discretion to arrest upon a reasonable suspicion that the suspect has committed an offence listed in schedule 1. Given the usage of the modal verb "may" and a number of choices available to the arrestor to bring the suspect before court, it defies logic to argue that once the arrestor has decided to arrest no questions could be raised as to why she did not use milder methods, even ex post facto. Even in the case of unlawful arrest, the court can, as the High Courts did, chart and define circumstances under which a lawful arrest could take place. Therefore, it cannot be argued that these cases are distinguishable to the extent that the application of section 39(2) of the Constitution is acceptable in one and not the other.

As the Sekhoto case did not displace the Govender case, the latter was binding on the former. This clearly, shows that the High Courts were justified in their formulation of the fifth jurisdictional fact and the Sekhoto case failed to follow precedent. In addition to the above, it is common cause that, in a constitutional state, courts should be wary of limiting the rights of individuals unless it is shown that such limitation is reasonable and justifiable. The police arrest powers must be measured against the standard of reasonableness. Absent reasonableness, police would arrest suspects who should not be subjected to arrest. In Khambule $v$ Minister of Police (2014 JOL 31721 (GSJ) parr 28-30) the court commented in this regard as follows:

[T] he available methods of securing that attendance in court are arrest, summons, written notice and indictment in accordance with the relevant provisions of the Criminal Procedure Act. Read with section 40(1)(a) this 
implies that where a warrantless arrest is permissible, the arresting peace officer must consider all factors relevant to the appropriate method of bringing the alleged offender before a court and balance them, the one against the other, for what might be justifiable in one case could constitute gross abuse of power in another ... It is clear that ... [the arrestor] simply proceeded with an arrest on the basis of an erroneous assumption (or pursuant to an errant official directive) that it was not his job, but that of some other official tasked with making a decision on an early release at some stage after the arrest ... Even if the [arrestor] was unsure as to whether, for example, a written notice to appear would be an appropriate alternative to an arrest because of considerations such as the identity of the plaintiff, a fixed residential address, etc., he had available to him another option. That option was an arrest for the purpose of the verification of such matter and as a precursor to a written notice to appear in court (own emphasis).

Why impinge on the rights of the subjects when less intrusive, yet equally potent means could be used? That would not be in keeping with the requirement of the rule of law. "Arrest is not an objective in itself ..." (Walters supra par 49).

\section{The Requirements for a Successful Claim based on the Fifth Jurisdictional Fact}

Although it does not explicitly say so, the SCA seems to realise that the only way to give effect to the right to freedom, where arrest without a warrant is concerned, is by recognising the fifth jurisdictional fact (Sekhoto supra par 45ff). This could be deduced from this passage (par 57):

The case can be disposed of on a simple basis, namely, that the proper exercise of [arrestor's] discretion was never an issue between the parties. The plaintiffs, who had to raise it either in their summons or in replication, failed to do so. The issue was also not ventilated during hearing. This means that since the magistrate had found that the four jurisdictional facts required for a defence under s 40(1)(b) were established by the appellant (a finding upheld by the court below) their claims had to be dismissed.

In this regard, the court held that if the plaintiff alleges failure to exercise discretion properly, the plaintiff must bear the onus of proof (par 49). The SCA concludes that for a claim of unlawful arrest, based on the fifth jurisdictional fact, to succeed, the plaintiff has to allege and prove it. Rules of evidence require that the plaintiff must make up its case with all jurisdictional facts, the fifth jurisdictional fact in particular (par 50). As previously stated, the SCA concluded by holding that the issue of the fifth jurisdictional fact was raised neither during the pleadings nor during the hearing.

It is clear that the conclusion of the SCA (which seems at odds with the reasons it advanced) is that the fifth jurisdictional fact is part of our law. The plaintiff would just need to allege and prove it. 


\section{Conclusion}

The formulation of the fifth jurisdictional fact sparked disagreements and dissents among different divisions of the High Court. The SCA was seized with the opportunity to reconcile the differing views among the High Courts. It is clear that the SCA leaned towards the rejection of the fifth jurisdictional fact. It has to be said, nonetheless, that the Sekhoto case was not ideal for the SCA to settle this question. This is due to the fact that the plaintiff's in this case failed to make their case with regard to the fifth jurisdictional fact. In other words, the plaintiffs' case was not based on the fifth jurisdictional fact on summons and same was not expressed during the trial. Therefore, some High Courts may find that the Sekhoto case is not binding on them. For instance, a High Court in which the issue of the fifth jurisdictional fact is pertinently raised in pleadings and in argument, may hold that it (a High Court) is justified in not following the Sekhoto case with regards to the question of the fifth jurisdictional fact, as this matter was not specifically raised in pleadings nor was it dealt with during trial. In other words, a High Court, in which the plaintiff has pleaded the fifth jurisdictional fact, may find that the Sekhoto case is distinguishable and therefore, not binding. At this moment, the last word on the question of the lawfulness of the fifth jurisdictional fact has not yet been spoken.

PR MSAULE

University of Limpopo 